\title{
KEBERADAAN SAN REMO MANUAL 1994 \\ DALAM KAITANNYA DENGAN UNCLOS 1982
}

\author{
ENNY NARWATI \\ Fakultas Hukum \\ Universitas Airlangga
}

\begin{abstract}
Pengaturan hukum perang di laut tidak mengalami perkembangan yang berarti sejak Konvensi Den Haag tahun 1907. Dengan adanya berbagai perkembangan yang ada memaksa masyarakat internasional untuk membuat berbagai penyesuaian berkaitan dengan pelaksanaan perang di laut. Perkembangan paling penting adalah dengan disahkannya UNCLOS 1982 di Montego Bay, Jamaika, yang berisi ketentuan tentang hak dan kewajiban Negara di laut. UNCLOS 1982 berlaku efektif pada tahun 1994. Semua ketentuan yang ada dalam UNCLOS 1982 berlaku pada masa damai, dan tidak ada satu ketentuanpun yang mengatur tentang penggunaan kekerasan ataupun peperangan. San Remo Manual 1994 berisi tentang pedoman pelaksanaan perang di laut. Karena itu perlu dikaji bagaimana kaitan antara San Remo Manual 1994 dengan UNCLOS 1982.
\end{abstract}

Kata kunci :UNCLOS 1982, San Remo Manual 1994, hukum perang di laut

\begin{abstract}
Setting the law of war at sea did not experience significant development since the Hague Convention of 1907. With the various developments that have forced the international community to make various adjusments relating to the conduct of the war at sea. The most important developments is the adoption of UNCLOS in 1982 in Montego Bay, Jamaica, which contains provisions concering the rights and obligations of the State in the sea. UNCLOS in 1982 became effective in 1994. All the provisions in the 1982 UNCLOS applies in peacetime, and no one rule governing the use of violence or war. 1994 San Remo Manual contains the guidelines for conduct of the war at sea. Because it needs to be studied how the link between the San Remo Manual 1994 with the UNCLOS 1982.

Key words :UNCLOS 1982, the San Remo Manual 1994, the law of war at sea

\section{PENDAHULUAN}

Hukum Internasional pada dasarnya dibagi menjadi dua, yaitu hukum yang berlaku pada masa damai dan hukum yang berlaku pada saat perang. Hukum yang berlaku pada masa

damai terdiri dari berbagai cabang hukum internasional, misalnya hukum laut internasional, hukum diplomatik dan konsuler, hukum perdagangan internasional, dan lain-lain. Sedangkan hukum yang berlaku pada saat perang
\end{abstract}


hanya ada satu, yaitu hukum humaniter internasional. Hukum Humaniter Internasional berisi sekumpulan peraturan yang mencakup semua ketentuan internasional yang berasal dari perjanjian dan kebiasaan internasional; yang bermaksud untuk mengatasi segala masalah kemanusiaan yang timbul pada waktu pertikaian bersenjata internasional maupun non-internasional; ketentuan tersebut membatasi atas dasar kemanusiaan, hak pihak yang terlibat dalam pertikaian bersenjata untuk menggunakan senjata dan metode perang tertentu; atau yang terkena pertikaian bersenjata melindungi orang yang menjadi korban maupun harta benda yang terkena akibat pertikaian bersenjata. (Anne Shopie Gindroz, 1996;1)

Secara garis besar Hukum Humaniter Internasional terdiri dari Hukum Jenewa dan Hukum Den Haag. Hukum Jenewa meliputi serangkaian ketentuan yang diterapkan selama pertempuran dan setelah pertempuran berakhir. Hukum ini mencakup semua perlindungan bagi pihak baik penduduk sipil maupun kombatan yang telah horse de combat. Hukum Den Haag merupakan serangkaian ketentuan yang berlaku dalam peperangan. Hukum ditujukan kepada para komandan militer beserta anak buahnya, yang menentukan hak dan kewajiban peserta tempur, dan oleh karena itu penerapannya terbatas pada waktu pertempuran sedang berlangsung. Perkembangan pengaturan hukum perang di darat mengalami kemajuan yang berarti dengan diterbitkannya Protokol Tambahan I dan II Tahun 1977. Tetapi, kiranya perkembangan hukum perang di laut bisa dikatakan tidak semudah perang di darat. Bisa dikatakan bahwa perkembangan hukum perang di laut tidak berhasil dilakukan, bahkan bisa dikatakan stagnan setelah Konvensi Den Haag 1907.

Sebenarnya negara-negara sudah berusaha untuk melakukan revisi terhadap Konvensi Den Haag 1907 untuk menyesuaikan dengan perkembangan yang ada, namun hal tersebut tidak membuahkan hasil. Berbagai peraturan telah dibuat, tetapi sampai dengan sekarang ini belum pernah ada perjanjian/konvensi internasional yang mempunyai kekuatan hukum mengikat.

Hal-hal yang menghambat perkembangan hukum perang di laut, diantaranya meliputi: Pertama, adanya Pasal 2 (4) Piagam PBB yang mengatakan bahwa negara-negara anggota PBB seharusnya tidak menggunakan kekuatan bersenjata dalam melaksanakan hubungan internasional dengan negara lain. Walaupun pasal ini tidak secara langsung melarang negaranegara untuk menggunakan kekuatan 
bersenjata, tetapi kewenangan negaranegara tersebut sudah sangat dibatasi. Hal ini mengakibatkan negara-negara enggan untuk membicarakan hukum perang karena khawatir disebut sebagai negara agresor. Kedua, adanya Pasal 51 Piagam PBB tentang self defence, yang memperbolehkan Negara-negara menggunakan kekuatan bersenjata hanya dalam rangka mempertahankan diri dari serangan yang dilakukan oleh Negara lain yang sudah mengganggu kedamaian serta keamanan internasional. Dari ketentuan pasal ini dapat dikatakan bahwa negara boleh berperang hanya karena melaksanakan self defence (pembelaan diri). Hal ini berarti self defence hanya boleh digunakan kalau sudah ada armed attack (serangan bersenjata) dari negara lain. Yang sering terjadi adalah negara yang bersangkutan akan melakukan serangan balasan. Dengan adanya serangan balasan ini maka dapat dikatakan negara yang bersangkutan sudah tidak lagi melakukan self defence. Dengan kata lain, kalau sudah terdapat armed attack, maka prinsip self defence sudah tidak dapat digunakan lagi. Jadi harus ada redefinisi tentang armed attack. (GPH. Haryomataram, 1995;88)

Walaupun terdapat beberapa hambatan seperti tersebut di atas, tetapi situasi yang berkembang kemudian memaksa negara-negara dan para ahli untuk melakukan perubahan atau penyesuaian ketentuan-ketentuan hukum perang di laut. Faktor-faktor yang mempengaruhi diadakannya perubahan ketentuan hukum perang dilaut yang meliputi : Pertama, adanya konvensi hukum laut internasional yang baru, yaitu United Nations Convention on the Law of the Sea (UNCLOS 1982). Dengan berlakunya UNCLOS 1982 ini maka wilayah laut dibagi-bagi menjadi beberapa zona, yang disetiap zona berlaku prinsip hukum yang berbeda. Hal ini secara langsung mempengaruhi daerah operasi perang di laut yang telah berlaku selama ini. Disamping itu berdasarkan UNCLOS 1982, terdapat hak negara lain untuk melakukan lintasan di wilayah laut suatu negara, yang berupa hak lintas damai, hak lintas transit dan hak lintas alur laut kepulauan, yang dalam keadaan-keadaan tertentu dibedakan antara kapal niaga dan kapal perang. Kedua, adanya Pasal 1 (4) Protokol Tambahan I tahun 1977. Pasal ini mengatur mengenai keadaankeadaan tertentu yang dikategorikan sebagai konflik bersenjata yang bersifat internasional (international armed conflict), yang meliputi CAR (colonial domination, alien occupation, racist regime) conlfict. CAR conflict ini dilakukan oleh bangsa-bangsa yang menuntut right to self determination. Hal ini berarti 
bahwa para pihak dalam international armed conflict tidak hanya negara saja, tetapi juga meliputi people (bangsa) yang sedang menuntut hak menentukan nasib sendiri (right to self determination) melalui perang kemerdekaan (war of national liberation). Apabila hal ini dikaitkan dengan pasal 29 UNCLOS 1982 maka akan terjadi suatu ketidakpastian, karena menurut pasal ini, kapal perang hanya dapat dimiliki oleh negara. Karena hanya negara yang dapat memiliki kapal perang, maka kemudian terjadi suatu kekosongan hukum yang berkaitan dengan status 'kapal perang' yang dimiliki oleh bangsa-bangsa yang menjadi pihak dalam international armed conflict yang termasuk dalam kategori CAR conflict tersebut. Ketiga, adanya jenis persenjataan-persenjataan baru yang digunakan oleh negara-negara dalam berperang. Dalam dua dekade terakhir telah ditemukan berbagai jenis senjata baru yang digunakan dalam berperang. Sebagai misal, dalam perang di laut, negara-negara menggunakan kapal selam yang tidak dikenal sebelumnya. Demikian pula dengan persenjataan lainnya, seperti penggunaan torpedo, ranjau, dan lain-lain.

Berkaitan dengan hal-hal tersebut di atas, maka mulai ada usahausaha dari negara-negara untuk mengatur sarana dan metode perang di laut.
Hal ini tidak mudah dilakukan, namun pada tahun 1994, akhirnya para ahli berhasil membentuk suatu pedoman yang bisa digunakan oleh negara-negara yang sedang melaksanakan perang di laut. Pedoman tersebut bernama San Remo Manual on International Law Applicable to Armed Conflik at Sea atau disebut San Remo Manual, yang diadopsi pada bulan Juni 1994 dalam pertemuan yang diadakan oleh International Institute of Humanitarian Law di San Remo, Italia. Sejak awal pembentukannya, para ahli memang sudah sepakat bahwa San Remo Manual tidak dibuat dalam bentuk perjanjian internasional yang mengikat negaranegara, tetapi hanya dibuat dalam bentuk manual saja, yang akan menjadi pedoman bagi negara-negara dalam menjalankan perang di laut. Hal ini berdasarkan pada latar belakang bahwa telah beberapa kali diupayakan untuk membuat suatu perjanjian internasional dalam bidang ini yang mengikat negaranegara, tetapi tidak berhasil.

San Remo Manual mengatur tentang hak dan kewajiban negara dalam melaksanakan perang di laut, yang meliputi: (a)laut teritorial, perairan pedalaman, wilayah daratan, zona ekonomi eksklusif dan landas kontinen, serta bila ada, perairan kepulauan dari negara-negara yang berperang; (b)laut 
lepas, dan zona ekonomi eksklusif dan landas kontinen negara-negara netral. Selain mengatur mengenai kawasan operasi peperangan yang diperbolehkan, San Remo Manual juga mengatur tentang sarana dan metode peperangan di laut, yang antara lain mengatur tentang persenjataan yang boleh digunakan bagi para pihak yang berperang.

Di sisi lain, pengaturan hukum laut internasional pada saat ini telah tertuang dalam UNCLOS 1982 yang telah berlaku secara efektif sejak Juli 1994, dimana semua ketentuan yang diatur hanya berlaku untuk masa-masa damai. Tidak ada satu ketentuanpun dalam UNCLOS 1982 yang memberi peluang kepada negara untuk melakukan perang di laut. Konvensi ini sama sekali tidak mengatur mengenai kemungkinan penggunaan kekerasan ataupun peperangan di laut. Berkaitan dengan uraian di atas maka yang akan menjadi kajian dalam penulisan ini adalah : Apakah kaitan San Remo Manual 1994 dengan UNCLOS 1982, atau dengan kata lain apakah San Remo Manual 1994 bertentangan dengan UNCLOS 1982 ?

\section{Zonasi laut menurut UNCLOS 1982}

Salah satu alasan dibentuknya San Remo Manual adalah adanya konvensi hukum laut internasional yang baru, yaitu United Nations Convention on the Law of the Sea (UNCLOS 1982). UNCLOS 1982 merupakan hasil dari Konferensi Hukum Laut III yang diselenggarakan oleh Perserikatan Bangsa-Bangsa, diotandayangani pada tanggal 10 Desember 1982 di Montego Bay, Jamaika. Pada tanggal 14 Juli 1994 UNCLOS 1982 telah berlaku secara universal karena telah diratifikasi oleh 60 negara.

Dengan berlakunya UNCLOS 1982 ini maka wilayah laut dibagi-bagi dalam beberapa zona, dimana disetiap zona berlaku prinsip hukum yang berbeda pula. Zona-zona tersebut meliputi : Perairan Pedalaman, Pengukuran zona-zona laut dimulai dari garis pangkal. Penentuan garis pangkal dibuat pada saat air laut paling surut. Perairan pedalaman merupakan perairan yang berada di antara daratan dan garis pangkal. Selain itu, perairan pedalaman juga meliputi wilayah pelabuhan, perairan yang berada di sebelah dalam suatu teluk, delta maupun mulut sungai. Terhadap perairan pedalaman ini berlaku kedaulatan negara pantai sama seperti kedaulatan negara di wilayah daratan. Laut Teritorial, merupakan wilayah laut yang berbatasan dengan garis pangkal. Dikatakan bahwa kedaulatan suatu Negara, selain wilayah daratan dan perairan pedalaman, perairan kepulauan 
bagi Negara Kepulauan, juga meliputi suatu jalur laut yang berbatasan dengan garis pangkal yang disebut sebagai laut territorial. Kedaulatan negara pantai atas laut territorial bersifat vertikal, mulai dari wilayah udara diatas laut territorial, perairan, serta dasar laut dan tanah di bawahnya. Lebar maksimum laut territorial yang boleh diklaim oleh suatu negara adalah 12 mil laut yang diukur dari garis pangkal. Tetapi yang perlu diperhatikan adalah kedaulatan negara atas laut territorial tidak sama seperti kedaulatan atas perairan pedalaman dan wilayah daratan. Di laut territorial, kapal-kapal negara asing mempunyai hak untuk melintas tanpa diganggu oleh negara pantai. Mengenai hal ini akan dibicarakan lebih lanjut pada sub bab di bawah. (a)Perairan Kepulauan, Yang dimaksud dengan perairan kepulauan adalah perairan yang berada di sebelah dalam dari garis pangkal kepulauan, yang menghubungkan pulau-pulau atau kepulauan yang yang menjadi bagian dari wilayah suatu Negara Kepulauan. Status perairan kepulauan hampir sama dengan laut territorial, yaitu berlaku kedaulatan negara kepulauan, hanya saja atas perairan kepulauan selain terdapat hak lintas damai bagi kapal asing, juga terdapat hak lintas alur laut kepulauan. Mengenai hak lintas alur kepulauan ini akan dibahas lebih lanjut pada sub bab di bawah. Zona Tambahan, merupakan suatu zona peralihan dari laut territorial, dimana berlaku kedaulatan negara pantai, ke laut bebas dimana berlaku asas kebebasan di laut. Terhadap zona tambahan ini negara pantai tidak lagi mempunyai kedaulatan, tetapi negara pantai masih diperbolehkan untuk melaksanakan yurisdiksinya atas pelanggaran-pelanggaran bea cukai, fiscal, saniter dan imigrasi yang dilakukan oleh kapal asing. Zona Ekonomi Eksklusif, merupakan suatu daerah di luar dan berdampingan dengan laut territorial, dimana terdapat hak-hak eksklusif dan yurisdiksi dari Negara pantai serta hakhak dan kebebasan-kebebasan dari Negara lain. Kewenangan negara atas ZEE meliputi hak berdaulat untuk keperluan eksplorasi dan eksploitasi, konservasi dan pengelolaan sumber kekayaan alam, yang meliputi perairan di atas dasar laut, dasar laut dan tanah di bawahnya. Kewenangan yang lain adalah memberlakukan yurisdiksi dalam hal pembuatan dan pamakaian pulau buatan, riset ilmiah kelautan dan perlindungan dan pelestarian lingkungan laut.

Pasal 58 menegaskan bahwa diluar kewenangan Negara yang telah disebut dalam pasal sebelumnya, maka bagi semua Negara, baik berpantai maupun tidak berpantai, berhak 
menikmati kebebasan pelayaran dan penerbangan, serta kebebasan meletakkan kabel dan pipa bawah laut, dan penggunaan laut lain yang sah menurut hukum internasional yang berkaitan dengan pengoperasian kapal, pesawat udara dan kabel serta pipa bawah laut. Pasal-pasal yang mengatur tentang penggunaan laut bebas juga berlaku di zona ekonomi eksklusif. Landas Kontinen, sebenarnya merupakan bagian dari ZEE, yang khusus meliputi dasar laut dan tanah dibawahnya, sebagimana disebutkan dalam pasal 76. Karena merupakan bagian dari ZEE, maka segala ketentuan yang ada di ZEE secara otomatis berlaku juga di landas kontinen, sepanjang tidak diatur secara khusus dalam pengaturan mengenai landas kontinen. Laut Bebas, merupakan semua bagian laut yang tidak termasuk dalam zona ekonomi eksklusif, dalam laut territorial atau perairan pedalaman suatu Negara, aau dalam perairan kepulauan suatu Negara kepulauan. Di laut bebas ini berlaku prinsip freedom of the sea. Kebebasan di laut berarti bahwa laut bebas dapat digunakan oleh Negara manapun. Kebebasan juga berarti bahwa tidak satupun Negara yang dapat menundukkan kegiatan manapun di laut bebas di bawah kedaulatannya dan laut bebas hanya digunakan untuk tujuantujuan damai. Kebebasan di laut meliputi
: kebebasan berlayar, kebebasan penerbangan, kebebasan untuk memasang kabel dan pipa bawah laut, kebebaan untuk membangun pulau-pulau buatan, kebebasan menangkap ikan serta kebebasan untuk melakukan riset ilmiah kelautan. Kebebasan di laut bebas ini tidak hanya dinikmati oleh Negaranegara yang mempunyai pantai saja, tetapi diperuntukkan bagi semua Negara. Area, merupakan daerah dasar laut dan tanah di bawahnya yang berada di luar yurisdiksi suatu Negara, yaitu di luar batas-batas landas kontinen yang berada dalam yurisdiksi suatu negara. Kegiatan di Area meliputi segala kegiatan eksplorasi dan eksploitasi sumbersumber kekayaan alam non-hayati. Kegiatan di Area tidak akan mempengaruhi status hukum perairan yang ada di atasnya ataupun ruang udara yang mengikutinya. Prinsip hukum yang berlaku di Area adalah common heritage of mankind, yang berarti bahwa segala kekayaan dan kegiatan di Area merupakan warisan bersama umat manusia, yang harus memberi manfaat bagi keseluruhan umat manusia yang ada di bumi tercinta ini.

Disamping pembagian zonazona laut di atas, kapal asing suatu negara mepunyai hak untuk melintas di laut territorial, peraira kepulauan dan selat internasional suatu negara. Hak 
lintas tersebut adalah: (a)Hak lintas damai, Mengenai hak lintas damai di laut territorial diatur dalam UNCLOS 1982 Bab II, Bagian 3, mulai pasal 17 - 32. Untuk lintas damai yang dilakukan di selat yang biasa digunakan untuk pelayaran internasional tercantum dalam pasal 45, sedangkan lintas damai yang dilakukan di perairan kepulauan diatur dalam pasal 52. Berdasarkan pasal 17, kapal semua negara, baik negara berpantai atau tidak, berhak menikmanti hak lintas damai melalui laut territorial suatu negara. Yang dimaksud dengan lintas adalah navigasi mel;alui laut terotorial untuk kepentingan : (i)melintasi laut tanpa memasuki perairan pedalaman atau singgah di tempat berlabuh di tengah laut, aatau fasilitas pelabuhan di luar perairan pedalaman; atau (ii)berlaku ke atau dari perairan pedalaman atau singgah di tempat berlabuh di tengah laut atau fasilitas pelabuhan tersebut.

Lintas yang dilakukan oleh kapal negara asing harus terus menerus, langsung dan secepat mungkin, Tetapi, untuk hal-hal tertentu, lintas juga mencakup berhentiu dan buang sauh, tetapi hanya sepanjang hal tersebut berkaitan dengan navigasi yang lazim atau perlu dilakukan karena force majeure atau mengalami kesulitan atau guna memberikan pertolongan kepada orang, kapal atau pesawat udara yang dalam bahaya atau kesulitan.

Pasal 19 memberikan pengertian mengenai lintas damai. Ayat 1 mengatakan bahwa lintas adalah damai sepanjang tidak merugikan kedamaian, ketertiban atau keamanan negara pantai. Lintas tersebut harus dilakukan sesuai dengan ketentuan UNCLOS 1982 dan peraturan hukum internasional lainnya. Lintas suatu kapal harus dianggap membahayakan kedamaian, ketertiban atau keamanan negara pantai apabila kapal tersebut melakukan salah satu kegiatan berikut: (i)setiap ancaman atau penggunaan kekerasan terhadap kedaulatan, keutuhan wilayah atau kemerdekaan politik negara pantai, atau dengan cara lain apapun yang merupakan pelanggaran asas hukum internasional sebagai mana tercantum dalam Piagam Perserikatan Bangsa-Bangsa; (ii)setiap latihan atau praktek senjata macam apapun; (iii)setiap perbuatan yang bertujuan untuk mengumpulkan informasi yang merugikan bagi pertahanan atau keamanan negara pantai; (iv)setiap perbuatan propaganda yang bertujuan mempengaruhi pertahanan atau keamanan negara pantai; (v)peluncuran, pendaratan atau penerimaan setiap pesawat udara di atas kapal; (vi)peluncuran, pendaratan atau penerimaan setiap peralatan dan perlengkapan militer; (vii)bongkar atau muat setiap komoditi, 
mata uang atau orang secara bertentangan dengan peraturan perundangundangan bea cukai, fiscal, imigrasi atau saniter negara pantai; (viii)setiap perbuatan pencemaran dengan sengaja dan parah yang bertentangan dengan ketentuan UNCLOS 1982; (ix)setiap kegiatan perikanan; (x)kegiatan riset atau survey; (xi)setiap perbuatan yang mengganggu setiap system komunikasi atau setiap fasilitas atau instalasi lainnya negara pantai; atau (xii)setiap kegiatan lainnya yang tidak berhubungan dengan lintas.

Dalam melakukan lintas damai, kapal selam dan kendaraan bawah air lainnya harus berlayar di atas permukaan air dan menunjukkan benderanya sebagaimana tercantum dalam pasal 20 . Dalam hal lintas damai ini, negara pantai diberi hak untuk membuat peraturan perundang-undangan mengenai : (i)keselamatan navigasi dan pengaturan lalu lintas maritim; (ii)perlindungan alatalat bantu dan fasilitas navigasi serta fasilitas atau instalasi lainnya; (iii)perlindungan kabel dan pipa bawah laut; (iv)konservasi kekayaan hayati laut; (v)pencegahan pelanggaran peraturan perundang-undangan perikanan negara pantai; (vi)pelestarian lingkungan negara pantai dan pencegahan, pengurangan dan pengendalian pencemarannya; (vii)penelitian ilmiah kelautan dan suevey hidrografi; (viii)pencegahan pelanggaran peraturan perundang-undangan bea cukai, fiskal, imigrasi atau saniter negara pantai.

Disamping mempunyai hak, negara pantai juga mempunyai kewajiban untuk tidak menghalangi lintas damai yang dilakukan oleh kapalm asing melalui laut teritorialnya, dengan persyaratan yang secara praktis berakibat penolakan atau pengurangan hak lintas damai, atau mengadakan diskriminasi formal atau nyata terhadap kapal negara manapun. Kewajiban yang lainnya, negara pantai harus mengumumkan secara tepat bahaya apapun bagi navigasi dalam laut teritorial yang diketahuinya.(b)Hak lintas transit, Pengaturan mengenai lintas transit tercantum dalam Bab III, Bagian 2, pasal $37-44$ UNCLOS 1982. Lintas transit berlaku bagi selat yang digunakan untuk pelayaran internasional, antara satu bagian laut bebas atau zona ekonomi eksklusif dan bagian laut bebas atau suatu zona ekonomi eksklusif lainnya. Selain itu juga tidak menutup kemungkinan bagi lintas melalui selat untuk maksud memasuki, meninggalkan atau kembali dari suatu Negara yang berbatasan dengan selat tersebut. Lintas ini merupakan pelaksanaan dari prinsip kebebasan pelayaran dan penerbangan dan harus dilakukan secara terus 
menerus, langsung dan secepat mungkin.

Kewajiban kapal dan pesawat udara sewaktu melakukan lintas transit meliputi: (i)lewat dengan cepat melalui atau di atas selat; (ii)menghindarkan diri dari ancaman atau penggunaan kekerasan apapun terhadap kedaulatan wilayah atau kemerdekaan politik Negara yang berbatasan dengan selat, atau dengan cara lain apapun yang melanggar asasasas hukum internasional yang tercantum dalam Piagam Perserikatan Bangsa-Bangsa; (iii)menghindarkan diri dari kegiatan apapun selain transit secara terus menerus, langsung dan secepat mungkin dalam cara normal kecuali diperlukan karena force majeure atau karena kesulitan;

Mengenai kapal yang digunakan untuk melakukan riset ilmiah kelautan dan kapal survey hisrografi, pada waktu melakukan lintas transit, tidak boleh melakukan kegiatan riset atau survey apapun tanpa ijin sebelumnya dari Negara tepi selat. Negara tepi selat mempunyai hak untuk menentukan alur laut yang akan digunakan untuk lintas transit dan juga menetapkan skema pemisah lalu lintas untuk pelayaran di selat. Hak lain yang dimiliki oleh Negara tepi selat adalah membuat peraturan perundangan-undangan yang bertalian dengan pelaksanaan lintas transit melalui selat.
Kewajiban Negara tepi selat dicantumkan dalam pasal 44 yang mengatakan bahwa Negara tepi selat tidak diperbolehkan menghambat pelaksanaan lintas transit yang dilakukan oleh kapal asing dan harus mengumumkan dengan tepat setiap adanya bahaya bagi pelayaran atau penerbangan di dalam atau di atas selat. Hak lintas alur laut kepulauan

Pada dasarnya hak lintas alur kepulauan sama dengan hak lintas transit. Apabila lintas transit dilaksanakan di selat yang biasa digunakan untuk pelayaran internasional, lintas alur laut kepulauan digunakan oleh kapal dan pesawat udara asing di perairan kepulauan suatu negara kepulauan. Hak lintas alur laut kepulauan bagi kapal asing diberikan sebagai kompensasi dari diakuinya konsepsi negara kepulauan. Hal ini karena dengan diterimanya konsepsi negara kepulauan oleh dunia internasional maka wilayah perairan yang sebelumnya berstatus sebagai laut bebas atau zona ekonomi eksklusif, dengan adanya konsep negara kepulauan maka statusnya berubah menjadi perairan kepulauan yang tunduk pada kedaulatan negara kepulauan. Perubahan status ini tentu saja sangat merugikan negara-negara maritim besar yang telah terbiasa melakukan pelayaran di tempat tersebut. Untuk mengakomodasi 
kepentingan-kepentingan negara-negara maritim tersebut maka diciptakanlah hak lintas alur laut kepulauan.

Hak lintas alur laut kepulauan diatur dalam pasal 53. Dikatakan bahwa suatu negara kepulauan dapat menentukan alur laut dan rute penerbangan di atasnya, yang cocok digunakan untuk lintas kapal dan pesawat udara asing yang terus menerus, langsung dan secepat mungkin melalui atau di atas perairan kepulauannya dan laut teritorial yang berdampingan dengannya. Dalam melaksanakan hak lintas tersebut, kapal dan pesawat udara harus menghormati alur laut yang berlaku. Dalam hal negara kepulauan dapat dilaksanakan melalui rute yang biasanya digunakan untuk pelayaran internasional. Selanjutnya dikatakan bahwa semua kapal dan pesawat menikmati hak lintas alur laut kepulauan. Dalam hal ini negara kepulauan tidak bolehmelakukan diskriminasi terhadap kapal dari negara tertentu. Jadi hak tersebut harus diberikan kepada semua kapal dan pesawat udara tanpa kecuali.

Hak lintas alur laut merupakan hak pelayaran dan penerbangan, dengan cara yang normal semata-mata untuk melakukan transit yang terus menerus, langsung dan secepat mungkin serta tidak terhalang antara satu bagian laut bebas atau zona ekonomi eksklusif dan bagian laut bebas atau zona ekonomi eksklusif lainnya. Dari ketentuan ini dapat ditarik kesimpulan bahwa untuk kapal selam yang didesain untuk berlayar di bawah permukaan air laut, maka pada waktu melakukan hak lintas alur laut kepulauan diperbolehkan untuk tidak berlayar di atas permukaan air.

Seluruh pasal-pasal yang terdapat dalam UNCLOS 1982 berisi ketentuan yang berlaku pada masa damai. Tidak ada satupun pasal yang mengatur tentang penggunaan kekerasan ataupun peperangan. Pasal 88 mengatakan bahwa laut bebas dicadangkan untuk maksud damai. Dari ketentuan ini dapat dikatakan bahwa penggunaan laut harus tetap dijaga hanya untuk tujuan-tujuan damai. Tetapi, dalam pasal 87 dikatakan bahwa laut bebas terbuka untuk semua negara, kebebasan laut bebas dilaksanakan berdasarkan syarat-syarat yang ditentukan dalam Konvensi dan ketentuan lain hukum internasional.

Disamping pasal yang mengatur tentang laut bebas, ketentuan serupa yang juga mengatur tentang penggunaan damai laut bebas terdapat dalam pasal 58 yang berlaku di zona ekonomi eksklusif. Pasal ini mengatakan bahwa di zona ekonomi eksklusif, semua negara, baik negara berpantai atau tak berpantai, menikmati, dengan tunduk pada ketentuan yang relevan Konvensi ini, 
kebebasan-kebebasan pelayaran dan penerbangan, serta kebebasan meletakkan kabel dan pipa bawah laut yang disebut dalam pasal 87 dan penggunaan laut lain yang sah menurut hukum internasional yang bertalian dengan kebebasan-kebebasan ini, seperti penggunaan laut yang berkaitan pengoperasian kapal, pesawat udara, dan kabel serta pipa bawah laut, dan sejalan dengan ketentuan-ketentuan lain Konvensi ini.

\section{San Remo Manual 1994}

Disisi lain, San Remo Manual 1994 dalam pasal 1 menentukan bahwa para pihak yang terlibat dalam konflik bersenjata di laut terikat oleh prinsip dan ketentuan hukum humaniter internasional yang berlaku sejak kekuatan bersenjata mulai digunakan. Selanjutnya, daerah peperangan di laut terdiri dari : (a)laut teritorial, perairan pedalaman, wilayah daratan, zona eksklusif dan landas kontinen, serta bila ada, perairan kepulauan dari negara-negara yang berperang; (b)laut lepas, dan (c)zona ekonomi eksklusif dan landas kontinen negara-negara netral. Sedangkan daerah yang dilarang untuk dijadikan kawasan operasi adalah wilayah Negara netral. Selain itu juga daerah laut dimana terdapat ekosistem yang langka atau habitat yang dilindungi, spesies atau bentuk lainnya kehidupan lingkungan laut yang dalam bahaya atau yang terancam. Lebih lanjut hal tersebut dijabarkan dalam pengaturan mengenai sarana dan metode peperangan. Dikatakan bahwa sarana dan metode peperangan harus dipergunakan dengan memperhatikan sebagaimana mestinya lingkungan alam sesuai yang diatur pada aturan hukum internasional. Pengrusakan atau penghancuran lingkungan alam yang tidak dibenarkan oleh kepentingan militer dan dilakukan dengan sengaja adalah dilarang.

Pada Bab II tentang Kawasan Operasi, Bagian I tentang Perairan Pedalaman, Laut Teritorial dan Perairan Kepulauan, diatur mengenai perairan netral. Perairan netral terdiri dari perairan pedalaman, laut teritorial dan, bila ada, perairan kepulauan negaranegara netral. Ruang udara netral terdiri dari ruang di atas perairan netral dan wilayah daratan negara-negara netral.

Didalam dan diatas perairan netral, termasuk perairan netral yang didalamnya terdapat selat internasional dan perairan dimana hak lintas laut alur kepulauan dapat dilaksanakan, aksi-aksi tempur oleh kekuatan-kekuatan bersenjata pihak yang berperang adalah dilarang. Negara netral harus mengambil beberapa tindakan, seperti pengamatan, untuk mencegah adanya pelanggaran 
tentang kenetralannya atau kekuatankekuatan bersenjata pihak yang berperang. (San Remo pasal 15) Larangan tersebut tidak menghilangkan hak bagi kapal asing, termasuk kapal dan pesawat udara pihak yang berperang untuk tetap menikmati hak lintas damai, hak lintas transit dan hak lintas alur laut kepulauan. Sejalan dengan hal tersebut, Negara netral tidak diperboleh menangguhkan pelaksanaan ketiga hak lintas tersebut. Perairan netral terdiri dari perairan pedalaman, laut teritorial dan, bila ada, perairan kepulauan negara-negara netral. Ruang udara netral terdiri dari ruang di atas perairan netral dan wilayah daratan negara-negara netral. Selanjutnya dikatakan bahwa Negara netral tidak diperbolehkan menangguhkan, mempersulit, atau dengan kata lain menghalangi hak lintas transit atau hak lintas alur laut kepulauan

Hak lintas transit dan lintas alur laut kepulauan yang berlaku di selat internasional dan perairan kepulauan pada masa damai tetap berlaku pada masa konflik bersenjata. Hukum dan peraturan dari negara-negara yang berbatasan dengan selat dan negara kepulauan yang berkaitan dengan lintas transit dan lintas alur laut kepulauan yang ditetapkan berdasar hukum internasional umum tetap diberlakukan. Kapal perang atas air, kapal selam, dan pesawat udara pihak yang berperang dan netral memiliki hak lintas transit dan lintas alur laut kepulauan melalui, di bawah, dan di atas semua selat dan perairan kepulauan dimana hak ini berlaku secara umum. Sebagai tambahan pada pelaksanaan hak lintas transit dan lintas alur laut kepulauan, kendaraan air dan kendaraan air serbaguna pihak yang berperang, dengan tunduk pada ketentuan paragraf 19 dan 21, dapat melaksanakan tindakan hak lintas damai di selat internasional netral dan perairan kepulauan sesuai dengan hukum internasional umum.

Pelaksanaan hak lintas damai tanpa penangguhan di selat internasional tertentu yang diakui oleh hukum internasional, tidak dapat ditunda selama berlangsung konflik bersenjata.

Dalam pasal 10 dikatakan bahwa salah satu kawasan peperangan yang diperbolehkan adalah zona ekonomi eksklusif negara netral. Hal tersebut diatur lebih lengkap dalam pasal 34 dan 35. Apabila aksi tempur dilaksanakan dalam zona ekonomi eksklusif atau pada landas kontinen negara netral, sebagai tambahan adanya ketentuan-ketentuan lain yang berlaku dalam hukum konflik bersenjata, pihak yang berperang harus menghormati sebagaimana mestinya hak dan kewajiban negara pantai, antara lain dalam eksplorasi dan eksploitasi 
sumber-sumber ekonomi di zona ekonomi eksklusif dan landas kontinen dan perlindungan serta pelestarian lingkungan laut. Disamping itu, mereka juga harus menghormati pulau-pulau buatan, instalasi bangunan serta kawasan aman yang ditetapkan negara netral di zona ekonomi eksklusif dan di landas kontinen.

Lebih lanjut dikatakan bahwa apabila pihak yang berperang menganggap perlu untuk menyebar ranjau di zona ekonomi eksklusif atau dilandas kontinen suatu negara netral, pihak yang berperang harus memberitahu kepada negara netral tersebut, dan harus menjamin antara lain bahwa luas daerah sebaran ranjau dan jenis ranjau yang digunakan tidak akan membahayakan pulau-pulau buatan, instalasi dan bangunan atau tidak akan mengganggu akses ke tempat tersebut dan harus menghindari sejauh mungkin gangguan yang timbul terhadap eksplorasi dan eksploitasi di zona tersebut yang dilakukan negara netral. Harus juga memperhatikan perlindungan dan pelestarian lingkungan laut.

Penggunaan laut bebas sebagai kawasan operasi yang diperbolehkan bagi para pihak melakukan peperangan diatur dalam pasal 36 dan 37. Aksi-aksi tempur dilaut lepas harus dilaksanakan dengan memperhatikan sebagaimana mestinya pelaksanaan hak ekplorasi dan eksploitasi sumber kekayaan alam dasar laut, dan dasar samudera, dan tanah di bawahnya yang berada di luar yurisdiksi nasional suatu negara netral. Pihak yang berperang harus hati-hati untuk menghindari kerusakan kabel dan jaringan pipa dasar laut yang tidak semata-mata digunakan untuk kepentingan pihak yang berperang.

\section{Hubungan San Remo Manual dengan UNCLOS 1982}

\section{Perang dan Hukum Perang}

Hukum perang sama tuanya dengan perang itu sendiri, dan perang sama tuanya dengan peradaban manusia di bumi. Jean Pictet mengatakan bahwa : "In reality, the laws of war are as old as war itself, and war is old as life on earth". (Jean Pictet, 1985;6) Lebih lanjut beliau mengatakan bahwa pengaturan pertama kali tentang perang sudah dimulai sejak 2.000 SM. Pada zaman tersebut, diantara bangsa-bangsa Sumeria, perang sudah merupakan suatu lembaga yang terorganisir. Hal ini ditandai dengan adanya pernyataan perang, kemungkinan mengadakan arbitrase, kekebalan utusan musuh dan perjanjian perdamaian. (Jean Pictet, 1985;7) Dalam kebudayaan Mesir kuno sebagaimana disebutkan dalam Seven Work of Mercy, menggambarkan adanya perintah untuk 
memberikan makanan, minuman, pakaian dan perlindungan kepada musuh, juga perintah untuk merawat yang sakit dan menguburkan mereka yang mati. Seorang tamu, bahkan musuhpun tak boleh diganggu. (Jean Pictet, 1985;8) Contoh lain pengaturan perang pada zaman kuno adalah apa yang terdapat dalam kebudayaan bangsa Hatitie. Pada masa itu, perang sudah dilakukan dengan cara-cara yang sangat manusiawi. Hukum yang mereka miliki didasarkan atas keadilan dan integritas. Mereka juga menandatangani pernyataan perang dan traktat. Para penduduk yang menyerah, yang berasal dari kota, tidak diganggu. Kota-kota yang telah diduduki, dimana penduduknya kemudian melakukan perlawanan, akan ditindak tegas. Peperangan antara Mesir dan Hatitie diakhiri dengan perjanjian perdamaian pada tahun 1269 SM.

Pengaturan mengenai peperangan juga dapat ditemukan di India. Dalam Undang-Undang Manu, yang merupakan pengaturan hukum internasional India kuno, diatur mengenai hak-hak tentara pendudukan, senjata yang dilarang dan perlakuan tawanan perang yang mirip dengan ketentuan hukum humaniter pada masa kini.

Pada abad-abad tengah, hukum perang dipengaruhi oleh ajaran-ajaran Agama Kristen, Islam dan juga asas kesatriaan. Ajaran Kristen memberikan sumbangan terhadap konsep perang yang adil atau just war. Ajaran Islam tentang perang antara lain dapat dilihat dalam Al Quran surat Al Bacará: 190, 191; an Anfal: 39; at Taubah: 5; al Haj:39, yang memandang perang sebagai sarana pembelaan diri, dan menghapuskan kemungkaran. Adapun prinsip kesatriaan yang berkembang pada masa ini misalnya mengajarkan tentang pentingnya pengumuman perang dan larangan penggunaan sensatasenjata tertentu. (Arlina Permanasari, 1999;15)

Pada zaman modern, dimulai dengan perang Napoleón sampai dengan terbentuknya Konvensi Den Haag 1899 dan 1907 dan Konvensi Jenewa 1949. Konvensi Den Haag 1899 dan 1907 berisi pengaturan tentang bagaimana perang dilakukan dengan benar, hak kewajiban para pihak dalam peperangan serta metode dan sarana berperang yang diperbolehkan. Sedangkan Konvensi Jenewa 1949 berisi ketentuan-ketentuan yang mengatur tentang pemberian perlindungan bagi para sorban peperangan, baik dari kalangan sipil maupun militer.

Disisi lain, sebenarnya hukum internacional sudah berupaya untuk membatasi negara-negara dalam menggunakan kekerasan bersenjata, 
mulai Konvensi Den Haag 1907, BrianKellog Pact 1928 sampai Piagam PBB. Walaupun begitu, yang terjadi dalam kenyataan yang ada, peperangan masih tetap terjadi sampai saat ini.

\section{Keterkaitan antara San Remo dengan UNCLOS 1982}

Seperti yang telah disebutkan pada awal tulisan, hukum internasional pada dasarnya dibagi menjadi dua, yaitu hukum yang berlaku pada masa damai dan hukum yang berlaku pada saat perang. Hukum yang berlaku pada masa damai terdiri dari berbagai cabang hukum internasional, misalnya hukum laut internasional, hukum diplomatik dan konsuler, hukum perdagangan internasional, dan lain-lain. Sedangkan hukum yang berlaku pada saat perang hanya ada satu, yaitu hukum humaniter internasional. UNCLOS 1982 merupakan salah satu hukum yang berlaku di masa damai, sedangkan San Remo Manual merupakan hukum yang berlaku pada masa perang.

Sejak tahun 1994 UNCLOS 1982 sudah menjadi suatu perjanjian internasional yang bersifat universal yang mengikat semua negara di dunia, tidak hanya bagi negara anggota, tetapi juga meliputi bukan negara anggota. Salah satu alasan mengapa UNCLOS 1982 harus berlaku universal, karena tidak mungkin dalam zona-zona yang ada berlaku hukum yang berbeda. Harus ada satu kesatuan hukum agar terjamin adanya statu kepastian hukum. Seluruh pasal-pasal yang terdapat dalam UNCLOS 1982 berisi ketentuan yang berlaku pada masa damai. Tidak ada satupun pasal yang mengatur tentang penggunaan kekerasan ataupun peperangan.

Disisi lain, San Remo Manual merupakan suatu pedoman yang bisa digunakan oleh negara-negara dalam melaksanakan peperangan di laut. Walaupun hanya berupa Manual, tetapi saat ini San Remo Manual telah digunakan oleh negara-negara dalam ketentuan hukum nasionalnya masingmasing. Hal ini oleh Laksamana Pertama Sunaryo, Kepala Dinas Hukum Markas Besar Angkatan Laut RI dalam acara Pelatihan yang diselenggarakan bersama antara Angkatan Laut RI dengan ICRC, tahun 2006.

Dari adanya dua ketentuan hukum di atas, yaitu UNCLOS 1982 dan San Remo Manual 1994, berkaitan dengan adanya keharusan satu kesatuan hukum yang berlaku dalam suatu daerah, maka dapat dipertanyakan, apakah hal itu dapat dikatakan bahwa San Remo Manual 1994 bertentangan dengan UNCLOS 1982? Untuk menjawab pertanyaan peneliti berusaha mengkaji 
dalam beberapa hal : (a)Dalam teori hukum, untuk menguji apakan terjadi konflik norma, dalam hal ini antara norma ketentuan yang terdapat dalam UNCLOS 1982 dengan San Remo Manual 1994, dapat digunakan beberapa macam cara. Salah satu cara adalah menggunakan asas prefensi (Philipus Mandiri Hadjon dan Tatiek Sri Djatmiati, 2005;3) Asas preferensi dalam teori hukum ada 3, yaitu: (i)Lex speciali(s) derogat legi generali(s), yaitu norma yang bersifat khusus mengalahkan norma yang bersifat umum. Contoh dalam hal ini adalah ketentuanketentuan yang diatur dalam Landas Kontinen mengalahkan ketentuanketentuan yang ada dalam Zona Ekonomi Eksklusif. Hal ini karena Landas Kontinen merupakan bagian dari Zona Ekonomi Eksklusif, sehingga segala ketentuan yang ada dalam Zona Ekonomi Eksklusif berlaku secara mutatis mutandis bagi Landas Kontinen, sepanjang tidak diatur secara khusus oleh Landas Kontinen. (ii)Lex posteriori derogat legi priori, yaitu bahwa ketentuan hukum yang kemudian mengalahkan ketentuan hukum yang terdahulu. Contoh : ketentuan-ketentuan yang terdapat dalam UNCLOS 1982 mengalahkan ketentuan-ketentuan yang ada dalam Konvensi Jenewa 1958 tentang Hukum Laut yang mengatur hal yang sama, yaitu hukum laut internasional. (iii)Lex superiori derogat legi inferiori, yaitu ketentuan hukum yang kedudukannya lebih tinggi mengalahkan ketentuan hukum yang lebih rendah. Contoh : 1993 FAO Agreement to Promote Compliance with International Conservation and Management Measures by Fishing Vessel on The High Seas tidak boleh bertentangan dengan UNCLOS 1982 karena kedudukan UNCLOS 1982 lebih tinggi Agreement yang dilakukan FAO dan juga Agreement tersebut untuk melaksanakan ketentuan-ketentuan yang ada dalam UNCLOS 1982, khususnya mengenai perikanan di Laut Bebas.

Asas-asas preferensi tersebut di atas dapat digunakan untuk membandingkan antara dua ketentuan hukum yang mengatur hal yang sama dan dalam ruang lingkup yang sama. Dalam kaitan hubungan antara San Remo Manual 1994 dengan UNCLOS 1982, tidak tepat untuk menggunakan asas preferensi karena, pertama, San Remo Manual 1994 bukan merupakan bagian UNCLOS 1982 dan kedua, San Remo Manual 1994 dan UNCLOS 1982 tidak mengatur hal yang sama, sehingga antara keduanya tidak dapat diperbandingkan. Yang menjadi persamaan antara keduanya hanya media yang digunakan adalah laut. UNCLOS 1982 merupakan 
ketentuan yang berlaku pada masa damai, sedangkan San Remo Manual 1994 merupakan ketentuan yang berlaku pada saat terjadi pertikaian bersenjata. Sehingga tidak bisa dikatakan saling bertentangan karena masing-masing mempunyai ruang lingkup yang berbeda, persamaannya hanya kejadiannya di laut. (b)San Remo Manual 1994 justru menyelaraskan dengan ketentuan yang ada dalam UNCLOS 1982, terutama mengenai kawasan operasi dan penggunaan metode dan sarana berperang di laut. Salah satu tujuan dibuatnya San Remo Manual adalah karena zona-zona laut sudah dibagi-bagi sedemikian rupa oleh UNCLOS 1982. Begitu juga dengan hak dan kewajiban negara-negara, seperti ketentuan tentang kewajiban terhadap pelestarian dan pengelolaan lingkungan laut, pelaksanaan hak lintas damai, lintas transit dan alur laut kepulauan. Pengaturan yang ada di dalam UNCLOS 1982 tersebut secara langsung mempengaruhi pelaksanaan sengketa bersenjata di laut. Hal ini dapat dilihat dari Explanation dari San Remo Manual 1994 yang mengatakan bahwa : "...Fourthly, given the important developments in other branches of international law, since the beginning of this century, namely, the law of the sea, the United Nations Charter, environmental law and air law, it was considered essential to evaluate the extent to which the law applicable to armed conflicfs at sea is affected by such developments." (Louise Doswald-Beck, 1994;62)

Penyesuaian tersebut dapat dilihat dari ketentuan tentang kawasan operasi yang meliputi wilayah laut para pihak yang berperang, juga tentang pelaksanaan hak lintas bagi kapal asing. San Remo Manual, Bab II tentang Kawasan Operasi merupakan perpaduan dari adaptasi doktrin dan prinsipprinsip tradisional dalam perang dilaut yang berlaku selama ini, khususnya mengenai hubungan para pihak yang berperang dengan negara netral di bawah yurisdiksi negara netral, dengan pengaturan yang ada di dalam UNCLOS 1982, khususnya mengenai pelaksanaan hak lintas damai, hak lintas transit dan hak lintas alur laut kepulauan.

Dalam UNCLOS 1982 sudah ditegaskan bahwa negara pantai tidak boleh menangguhkan pelaksanaan hak lintas kapal asing di perairan yang berada di bawah kedaulatannya, termasuk juga hak lintas yang dilakukan oleh kapal asing yang sedang menjadi pihak dalam peperangan. Tetapi, di sisi lain, kapal asing yang sedang menikmati hak lintas juga harus menghormati hak-hak negara pantai dan dilarang melakukan aksi tempur. Termasuk dalam menghormati negara pantai, misalnya pada 
saat melakukan lintasan kapal tersebut harus menyimpan rapat-rapat persenjataannya dan menghindarkan diri dari kegiatan-kegiatan yang membahayakan negara pantai/netral. Hal-hal berikut termasuk dalam kategori aksi tempur : (i)Menyerang atau menangkap orang atau obyek yang berlokasi di laut dan atau udara di atas perairan atau daerah negara netral; (ii)Menggunakan wilayah negara netral untuk pangkalan operasi, termasuk menyerang atau menangkap orang atau obyek yang berlokasi di luar perairan netral, bila penyerangan atau penyitaan dilakukan oleh kekuatankekuatan bersenjata pihak yang berperang berlokasi di laut dan atau udara di atas perairan netral; (iii)Menyebarkan ranjau, atau (iv)Memeriksa, mencari keterangan, membelokkan arah atau menangkap.

Salah satu daerah yang boleh digunakan untuk pelaksanaan perang di laut adalah zona ekonomi eksklusif negara netral. Secara sepintas hal ini sepertinya melanggar hak negara netral atas zona ekonomi eksklusifnya. Seperti diketahui bahwa kewenangan negara pantai di zona ekonomi eksklusif meliputi hak berdaulat untuk melakukan konservasi dan pengelolaan sumbersumber kekayaan alam, termasuk di dalamnya yurisdiksi eksklusif atas pulau-pulau buatan dan instalasi- instalasi lepas pantai, riset ilmiah kelautan dan perlindungan serta pelestarian lingkungan laut. Diluar kewenangan negara pantai tersebut, maka yang berlaku adalah ketentuan-ketentuan tentang laut bebas, khususnya meliputi kebebasan pelayaran dan penerbangan, dan kebebasan meletakkan kabel dan pipa bawah laut. Sehingga ini berarti daerah tersebut bebas digunakan oleh negara-negara lain, termasuk di dalamnya untuk kawasan operasi perang. Secara tradisional, salah satu kawasan operasi perang di laut yang paling menonjol adalah laut bebas. Dengan adanya UNCLOS 1982 maka terdapat perkembangan baru dimana negara pantai mempunyai hak berdaulat di wilayah laut di luar laut terirotial, sehingga pelaksanaan hukum perang di laut juga harus menyesuaikan dengan ketentuan tersebut. Penyesuaian tersebut kemudian diatur dalam pasal 34 dan 35 San Remo Manual 1994 yang pada dasarnya mengatakan bahwa zona ekonomi eksklusif negara netral boleh digunakan sebagai kawasan operasi para pihak yang bertikai, tetapi tetap harus memperhatikan hak-hak negara pantai yang ada di zona tersebut.

\section{Keberlakuan San Remo Manual 1995 di Indonesia}

San Remo Manual 1994 
dipersiapkan sejak tahun 1988 oleh sekelompok ahli hukum internasional dan anggota angkatan laut yang bertindak dalam kapasitas sebagai individu masing-masing dalam suatu Round Table yang diprakarsai oleh International Institute of Humanitarian Law. Usaha modernisasi hukum perang dilaut sudah dimulai pada tahun sebelumnya, 1987, dalam Round Table yang diselenggarakan di San Remo yang diselenggarakan oleh International Institute of Humanitarian Law bekerja sama dengan Universitas Pisa dan Universitas Syracuse New York yang membicarakan tentang perlunya memperbarui hukum untuk sengketa bersenjata di laut.

Menurut hukum internasional, San Remo Manual yang hanya merupakan pedoman yang dibuat oleh para ahli tidak dapat digunakan sebagai sumber hukum internasional karena tidak mempunyai kekuatan mengikat. Sejak awal pembentukannya, para ahli memang sudah sepakat bahwa San Remo Manual tidak dibuat dalam bentuk perjanjian internasional yang mengikat negara-negara, tetapi hanya dibuat dalam bentuk manual saja, yang akan menjadi pedoman bagi negara-negara dalam menjalankan perang di laut. Hal ini berdasarkan pada latar belakang bahwa telah beberapa kali diupayakan untuk membuat suatu perjanjian internasional dalam bidang ini yang mengikat negara-negara, tetapi tidak berhasil. Tetapi, walaupun masih berupa suatu pedoman, San Remo Manual 994 sudah digunakan oleh negara-negara dalam melakukan perang di laut dan juga dalam pertemuan-pertemuan internasional yang membicarakan masalah perang di laut.

Bagi Negara Kesatuan Republik Indonesia, dapat dikatakan bahwa pada saat ini San Remo Manual 1994 sudah digunakan oleh Indonesia, khususnya oleh TNI Angkatan Laut. Hal ini bisa dilihat dari berbagai kegiatan yang menggunakan San Remo Manual 1994 sebagai dasar pelaksanaan berbagai kegiatan tersebut. (a)Pada tahun 2002, Markas Besar TNI Angkatan Laut, bersama-sama dengan ICRC telah berhasil menerjemahkan San Remo Manual 1994 dalam edisi Bahasa Indonesia. Dalam Kata Sambutan, Kepala Staf TNI Angkatan Laut pada saat itu, Laksamana TNI Bernad Kent Sondakh, mengatakan bahwa : 'dengan diterbitkannya buku ini, saya harapkan setiap prajurit TNI AL dapat mempedomaninya untuk semakin memahami dan mengerti hal-hal yang boleh dilakukan dan wajib dilakukan serta yang tidak boleh dilakukan dalam menjalankan tugasnya sehingga dapat menghindari kegagalan pelaksanaan 
tugas dan aspek hukum.'; (b)Pada tahun 2003, TNI AL bekerja sama dengan ICRC membuat buku Bahan Ajar Berperang Dengan Benar yang ditujukan kepada segenap prajurit TNI Angkatan Laut, termasuk didalamnya lembagalembaga pendidikannya. Bahan Ajar tersebut merupakan penjabaran dari Hukum Perang, baik meliputi Konvensi Den Haag, Konvensi Jenewa maupun San Remo Manual yang berlaku untuk perang di laut, sehingga buku tersebut merupakan bekal besar bagi seluruh prajurit perwira, bintara dan tamtama sesuai tingkatan yang bertugas di kapal, pesawat udara, pangkalan, staf serta pasukan (marinir); (c)Diseminasi atau sosialisasi yang dilakukan oleh TNI Angkatan Laut ataupun yang melibatkan TNI Angkatan Laut kepada para prajurit maupun staf pengajar di perguruan tinggi seluruh Indonesia; (d)Dalam seminarseminar dan pelatihan-pelatihan yang diadakan oleh TNI Angkatan Laut atau yang melibatkan TNI Angkatan Laut, dimana peneliti sering hadir, selalu menggunakan San Remo Manual sebagai dasar pembicaraan topik terkait.

\section{PENUTUP}

Dari uraian di atas dapat diambil suatu kesimpulan bahwa tidak ada pertentangan antara San Remo Manual dengan UNCLOS 1982, karena keduanya merupakan ketentuan hukum yang saling berbeda ruang lingkup pengaturannya. UNCLOS 1982 merupakan serangkaian aturan hukum internasional di laut yang berlaku pada masa damai, sedangkan San Remo Manual merupakan aturan hukum yang berlaku pada saat peperangan. Disamping itu, salah satu tujuan dibuatnya San Remo Manual adalah untuk menyelaraskan ketentuanketentuan mengenai hukum perang di laut dengan hukum laut yang berlaku saat ini, yaitu UNCLOS 1982. Indonesia, khususnya TNI Angkatan Laut telah menggunakan San Remo Manual 1994 sebagai dasar pelatihan bagi para prajurit dan juga dalam kegiatan-kegiatan lainnya.

\section{DAFTAR PUSTAKA}

Arlina Permanasari dkk., (1999). Pengantar mHuku Humaniter, ICRC, Jakarta

Churchill, V., Lowe, (1999). The Law of the Sea, third edition, Manchester University Press, Great Britain

Departemen Luar Negeri RI, United Nations Convention on the Law of the Sea (Bahasa Inggris dan Indonesia)

Direktorat Jendral Hukum dan Perundang-undangan Departemen Kehakiman, (1999). Terjemahan Konvensi Jenewa Tahun 1949, Direktorat Jendral Hukum dan Perundang-undangan Departemen 
Kehakiman, Jakarta

Gindroz, Anne Sophie, Sejarah dan Sumber Hukum Humaniter Internasional, (1996). Course Material on International Humanitarian Law, Kerjasama Pusat Studi Hukum Humaniter Fakultas Hukum Trisakti dengan International Committee of the Red Cross (ICRC) dalam rangka Penataran Hukum Humaniter, Cipayung

Green, L.C., (2000). The Contemporary Law of Armed Conflict, Second Edition, Juris Publishing, Mancester University Press, Great Britain

Haryomataram, (1995). Ceramah pada Penataran Hukum Humaniter, tanggal 25 Juli 1995 , diselenggarkan oleh Pusat Studi Hukum Humaniter Fakultas Hukum Trisakti, Jakarta

, (1994). Sekelumit tentang Hukum Humaniter, Sebelas Maret University Press, Surakarta,

International Institute of International Law, (1994). San Remo Manual on International Law Applicable to Armed Conflicts at Sea, Prepared by international lawyers and naval experts convened by the International Institute of International Law ${ }_{2}$ San Remo, Italy

Louise Doswald-Beck, editor, (1994). San Remo Manual on International Law Applicable to Armed Conflicts at Sea, Prepared by international lawyers and naval experts convened by the International Institute of International Law, Explanation, International Institute of International Law San Remo, Italy

Markas Besar TNI Angkatan Laut, (2002). San Remo Manual tentang Hukum Internasional Yang Berlaku Untuk Perang Di Laut, Jakarta

Philipus Mandiri Hadjon dan Tatiek Sri Djatmiati, (2005). Argumentasi Hukum, Gajah Mada University Press, Jogyakarta

Pictet, Jean, (1985). Development and Principles of International Humanitarian Law, Martinus Nijhoff Publishers 